\title{
LINGUISTIC AND PHILOSOPHICAL FOUNDATIONS OF THE DEBATE IN COMMUNICATION
}

\author{
Feruzakhon Karimova
}

Junior Research Fellow (Phd) Institute Of Uzbek Language, Literature And Folklore Of The Academy Of Sciences Of The Republic Of Uzbekistan

\section{ABSTRACT}

The article reflects the theoretical-philosophical and linguistic aspects of the debate and controversy in communication. His obedience to the principle of logic is proved by examples.

KEYWORDS: - linguistics, communication, philosophy, logic, strategy.

\section{INTRODUCTION}

The term debate is synonymous with the word eristics, which in ancient Greek means "art of debate". It was originally used by the Sophists. Aristotle in his time described eristics as "the art of unbiased debate": "Through this art, you can prove your right in any dispute, even if you are behind the truth", he said [1]. Eristics is the process by which a person constantly strives to prove that he or she is right, and it occurs in many situations: in the family, at work, in scientific discussions, in public debates, and in conversations. The work of the German philosopher A. Schopenhauer "The Art of Swallowing in Debate" is one of the best works written in the XIX century, which describes the methods of winning 33 disputes, using the methods of the ancient Sophists [2, pp. 523-548]. But researchers have expressed their views that not all of them are impartial. Everyone's desire to win the contest is therefore strong: "Our brains are very nervous about anything related to intellectual powers, and we don't want to agree that what we said before was wrong and what the opponent said was right" [2, p. 512]. In order to win the debate, it is very important to be aware of logical knowledge. The bridge between logic and linguistics is firmly established in the science of the ancient world, in which the Sophists, from Socrates to Aristotle to Farobi and Ibn Sina, based their knowledge on the concepts. According to the laws of thinking, the conclusion reflects in a generalized, abstract way the things and events in the objective being, the various relations and connections between them. At the same time, he always adheres to the principle of truthfulness, that is, he reflects the events of existence as true as possible [3, p. 17]. Hence, contemplation serves man to reflect the world accurately and truthfully. With the help of language, knowledge is collected, synthesized, generalized, conclusions are drawn and passed from one generation to another. Language is, in essence, subject to the principles of objectivity, logic, 
CURRENT RESEARCH JOURNAL OF PHILOLOGICAL SCIENCES 2(9): 100-

104, September 2021

DOI: https://doi.org/10.37547/philological-crjps-02-09-22

ISSN 2767-3758

(C)2021 Master Journals

Crossref do

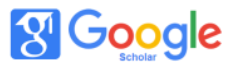

Accepted25 $5^{\text {th }}$ September, 2021 \& Published $30^{\text {th }}$ September, 2021

evolution, and historicity. Therefore, the unity of language and thought has long united such areas as logic, dialectics, rhetoric, eristics, for which it has served and continues to serve as a common source. It is natural and necessary for every science to be based on logic. The science of logic is also inextricably linked with the science of language. Linguist A.Nurmanov writes about this in his monograph "Syntactic Theories of Speech": The phenomenon of prediction is not only the basis of speech, but also the basis of judgment. Traditional logic stems from the attributive nature of judgment. Accordingly, the sentence structure always consists of a subject and a predicate. Its formula is $S+R$ or $\operatorname{not} S+\mathrm{R}^{\prime \prime}[4$, p. 26].

\section{THE MAIN FINDINGS AND RESULTS}

Ways to win the debate will also be linked to logic. Debate is a term of strategy along with the art of eristics. The term is said to have been coined by European Researchers R. Green and H. F. Zenger [5, p. 55]. Although strategies first appeared in China as a military science, it should be noted that later as a science of thinking and coping in several fields, including in the folklore of the peoples of the East, it is found in the example of mental persecution of characters like Nasriddin Efendi [5, p. 59].

Reflecting on the origins of debate and controversy, J. Rumi, one of the philosophers of the East, emphasizes that they are based on worldly interests and cites the following remarkable narration.

"When four people from four nations - Turks, Persians, Arabs and Greeks - go on a journey together, someone gives them a dirham. The four of them quarreled over what to buy with the money because they did not understand each other's language: when the Persian said "we will get grapes", the Arab said "I do not eat grapes, I want inab (grapes)". While the Turks insist on getting "grapes", the Greeks say, "No, I want to eat istofil (grapes)". As a result, they do not understand each other and walk side by side. At that moment, when a man with a hundred secrets spoke, listened to their arguments, took the money from them, and bought grapes from the market, all four of them were amazed to see that he wanted something, and their wishes came true and they reconciled [6, pp. 8-11]. Of course, J. Rumi cited this narration to figuratively emphasize that, despite the diversity of religions, it essentially leads to one destination. At the same time, the philosopher-scientist argues through narration that material or spiritual interests underlie the controversy. We say that the spiritual or material interests of a person are at the heart of the debate.

R. Gelgardt, one of the Russian linguists of the 20th century, also expressed his opinion on the movement of the participants of the dialogue in terms of interests: "Dialogue is conducted in a certain pattern: interest - the answer to the interest" [7, p. 58]. What is said for "benefit" comes from the reaction to something, from the evaluation. The attitude depends on how the speaker assesses the situation. "The basic principle of evaluation is that the world exists for man, man is not for the world. Therefore, the basis of any assessment is a person's needs to one degree or another" [8, p. 80]. It would be fair to say that the rating category plays a specific role in the communication category here. Assessment and its status in a particular language will be inextricably linked with the socio-cultural norms of that language. The role of the assessment category at the language level, its role in opening the process of communication has a philosophical, sociopsychological character. Objective and subjective assessment stems from an approach to understanding the world, and the speaker who expresses the value also helps to determine his or her own assessment.

Modern rhetoric, the rules of debate, cite some popular methods by which it is easy to win a debate. At the heart of these rules are examples of the art of 
CURRENT RESEARCH JOURNAL OF PHILOLOGICAL SCIENCES 2(9): 100-

104, September 2021

DOI: https://doi.org/10.37547/philological-crjps-02-09-22

ISSN 2767-3758

(C)2021 Master Journals

Crossref do

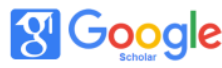

Accepted25 $5^{\text {th }}$ September, 2021 \& Published $30^{\text {th }}$ September, 2021

debate in ancient China and ancient Greece [9, pp. 82-110].

Method 1

It is easy to attack in an expanded mind, but difficult in a narrowed mind. In doing so, you should try to express the idea as clearly as possible. For example, it is more accurate to say "I have a lot of knowledge on social psychology" rather than "I understand modern Uzbek literature of the 20th century" rather than "I know psychology well". Then the opponent will not be able to break out of the boundaries of the opposite side. In doing so, the competing party will have to maintain its data boundary. The opposing side is forced to respond on its own without being able to go beyond the knowledge within the boundaries.

\section{Method 2}

A way to always be in a high position when responding to objections. It is not always possible to prevent disagreements and conflicts. So you also need to know how to be competitive. In the discussion, it is both important and useful to better understand other people's opinions, share ideas, and find mutually beneficial ways. The evidence presented helps to understand the problem. It is important not only to present your own arguments in the dispute, but also to respond correctly to the arguments of the other party. The play on the art of management and public speaking provides some advice on debate tactics. In particular, the methods of gathering evidence, breaking the chain of evidence, and burdening the opponent with the burden of proof are applied in a certain sequence and in a coherent manner. There are 3 ways to respond to evidence. They are:

1. Opposition to evidence that the opponent believes.

2. To object to his findings.

3. Accepting the arguments of the opposing party, but presenting evidence that is superior to his. However, it is also important to be able to listen in any situation. It is important to listen carefully and study the argumentation process of the opposing party. Then the opponent's counter-arguments will be revealed, and it will be possible to consider them. Also, once you know the opponent's side, keeping it at that point is also the advantage of a vigilant debater. Then he will not be able to get out of his circle and will have to give up. For such situations, the important thing is to listen and learn from the other side. Example:

- Bo'ldi, - dedi bola bir mahal.

- Nima bo'ldi?

- Bo'ldi, o'yin tamom! - deya qiqirlaydi Kuntug'mish.

- Bahrom taxtaga zehn solib chiqadi -yu, taxta bo'lib qoladi.

- Tirmizak! - deydi achchiqlanib va kaftining orqasi bilan bir urib shaxmat taxtasini ag'darib tashlaydi. Donalar gulzorga sochilib ketadi. Jahl bilan o'rnidan turganida xarrakning bola o'tirgan tarafi bosib, Kuntug'mish erga qulaydi.

- So'zingizda turasizmi endi?- deb so'raydi "groysmester" dumalab yotgan joyidan.

- Bahrom lovullab baqiradi:

- Qanaqa so'z?!

- $\quad$ Toshkent, sponsorlik masalasi...

- Huv dadang qilsin sponsorlikni!

- Dadam... Billa ketamizmi?

- Borsang, ana, o'zing boraver! Ota seniki! Bozor iqtisodiyoti!

Cho'ntagidagi sigaretini paypaslay-paypaslay Bahrom zarda bilan hovlini tark etadi. [Erkin Azam. Debtor].

"That's enough". said the boy once.

"What happened?"

- That's it, the game is over! Cried Kuntugmish.

- Bahrom looks at the board and becomes a board.

- Tirmizak! He said angrily, knocking the 
CURRENT RESEARCH JOURNAL OF PHILOLOGICAL SCIENCES 2(9): 100-

104, September 2021

DOI: https://doi.org/10.37547/philological-crjps-02-09-22

ISSN 2767-3758

(C)2021 Master Journals

Crossref do

chessboard over with the back of his palm. The grains are scattered in the flower bed. When he gets up angrily, the child sitting on the side of the harpoon falls to the ground.

"Do you keep your word now?" The grandmaster asked as he rolled over.

Bahrom shouts:

"What word?"

- Tashkent, the issue of sponsorship ...

"Let your father sponsor it!"

"Dad ... Shall we go, together?"

"If you go, go yourself!" Dad yours! Market economy!

Feeling the cigarette in his pocket, Bahrom leaves the yard with a grin.

What word in this dialogue?!, If you go, go, go yourself! Dad yours! Market economy! such arguments can be said to have served for an unequivocal 'victory'. Winning in such 'victories' never pleases the 'winner', nor does it evoke the joy of victory, but the dissatisfaction with one's own behavior.

The analysis of this example also leads to the conclusion that the controversial chess game and the victory of the younger generation over the older generation and the weak pride of the older generation who could not accept it and did not want to admit it could not give up their interests. The desire to win prevailed over the common interests of both parties (going to Tashkent, looking for the child's father), which also led to mental decline.

Method 3 Method of distribution or generalization. The stronger the generalization of the phrase quoted, the greater the scale and difficulty of the response or attack. This method is also interpreted as a method of "lubricating" or flattering the evidence [9, p. 98]. Example:

- Chiroyli ayollarni ko'rganda miyamga g'alati fikrlar quyulib kelaveradi,- dedi G'aybarov battar avj qilib. - Biram dadil, biram hur fikrlarki, yuragim tars yorilay deydi!..

- Bunaqa fikr uchun sizni toshbo'ron qilish kerak,
- dedi Zamira jilmayganicha.

- Muncha zolimlik! Kim u, mendan rostgo'yroq bo'l, deb talab qiladigan?

- Rostgo'ylik ham evi bilan - da...

- Nima, sal oshirib yubordimmi? - deb talmovsiradi G'aybarov.

- Rost gap odobga zid bo'Imasligi kerak.

- Alvido, hur fikr, asov g'alayon!... - deb xitob etdi G'aybarov qo'llarini namoyishkorona yozib. Rost gapni doim ta'qib qilishgan. Uni deb odamlarni o'ldirishgan, yoqishgan, tiriklayin terisini shilib olishgan!.. Qur'on, Tavrot, Injil, Talmud va sanoqsiz vedalar! Shariat va inkvizitsiya, ming xil taqiq!.. Hur fikrga omonlik bormi o'zi?

- Zamira ortiq kulmay qo'ydi.

- Bas endi, - dedi ozorlanib. - Nega o'zingizni mayna qilasiz? Axir, siz aslida bunaqa emassiz ku? (M.M. Dost. Return to Galatepa or narrated by the blessed Gaybarov).

"When I see beautiful women, strange thoughts come to my mind", said Gaybarov. "I'm so brave, I'm so free, my heart is pounding!"

"You should be stoned for such an idea", said Zamira, smiling.

"So cruel!" Who would want him to be more honest with me?

- Honesty is with the house ...

- $\quad$ "Did I exaggerate a little?" Said Gaybarov.

- The truth should not contradict etiquette.

"Good-bye, free thought, fierce revolt!" Cried Gaybarov, writing his hands in protest. - The truth has always been followed. They killed people, burned them, and skinned them alive! The Qur'an, the Torah, the Bible, the Talmud, and countless Vedas! Sharia and the Inquisition, a thousand kinds of prohibitions!

Zamira stopped laughing.

"Now" he said angrily. "Why are you mocking yourself?" After all, you're not really like that, are you?

Zamira "regretted, biting her lip" from Gaybarov's 
CURRENT RESEARCH JOURNAL OF PHILOLOGICAL SCIENCES 2(9): 100-

104, September 2021

DOI: https://doi.org/10.37547/philological-crjps-02-09-22

ISSN 2767-3758

(C2021 Master Journals

Crossref dit) 81 Google

Accepted25 $5^{\text {th }}$ September, 2021 \& Published $30^{\text {th }}$ September, 2021

distracting way of giving examples. In this text, we see the use of an impartial method in the communication process.

\section{Conclusion}

To conclude, it can be said that the debate type of communication has its own philosophical and logical principles. While impartial methods in it are subject to logic, impartial methods lead to communication failure.

\section{ReFERENCES}

1. http://loveread.ec/read_book.php?id=55235\& p=12\#gl_8 Herring J. The Art of Polemics. How to discuss energetically, convincingly, confidently. Source: http://loveread.ec/read_book.php?id=55235\& $\mathrm{p}=12 \# g \mathrm{gl} 8$

2. Schopenhauer A. (2018) The world as will and representation. Aphorisms of worldly wisdom. Eristics, or the art of winning controversy. Moscow: Eksmo. - Moscow. - pp. 523-548. (Шопенгауер А. Мир как воля и представление. Афоризми житейской мудрости. Эристика, или исскуство побеждать в спорах. - М.: Эксмо, 2018. - С. 523-548.)

3. Khayrullaev M., Haqberdiev M. (1993) Logic. Tashkent: Teacher. - p. 17. (Хайруллаев M., Хақбердиев М. Мантиқ. - Тошкент: Ўқитувчи, 1993. - Б. 17.)

4. Nurmonov A. (1988) Syntactic theories about speech. - Tashkent. - p. 26. (Нурмонов А. Гап хақида синтактик назариялар. - Тошкент, 1988. - Б. 26.)

5. Alimasov V. (2008) Philosophy or the art of thinking. - Tashkent: Noshir. - p. 55. (Алимасов В.Фалсафа ёхуд фикрлаш санъати. - Тошкент: Noshir, 2008. - Б. 55.)
6. Rumiy J. (1999) Masnaviyi spiritual. Tashkent: Sharq. - pp. 8-11. (Румий Ж. Маснавийи маънавий. - Тошкент: Шарқ, 1999. - Б. 8-11.)

7. Helgardt R.R. (1971) Reasoning about dialogues and monologues. Collection of reports and messages of the linguistic society. Issue I. - Kaliningrad. - p. 58. (Гельгардт P.P. Рассуждение о диалогах и монологах. Сборник докладов и сообщений лингвистического общество. Вып .І. Калинград, 1971. - С. 58.)

8. Pardaev Z. (2012) Pragmatic content and evaluation approach. Uzbek language and literature. - Tashkent. - №4. - p. 70. (Пардаев 3. Прагматик мазмун ва бахолаш муносабати // Ўзбек тили ва адабиёти. Тошкент, 2012. - №4. - Б. 70.)

9. Saidov U. (2011) The art of management and public speaking. - Tashkent: Gafur Gulom Publishing House. - pp. 82-110. (Саидов У. Бошқарув ва нотиқлик санъати. - Тошкент: Ғафур Ғулом номидаги нашриёт-матбаа ижодий уйи, 2011. - Б. 82-110.)

10. Rasuljanovna, I. N. (2019). Lacunas Occurance In Semantic Fields of Chinese And Uzbek Languages. International Journal of Scientific \& Technology Research, 8(11), 1998-2001. 